\title{
Achievement Motivation for Introductory College Biology
}

\author{
Marcus Lee Johnson \\ Developmental and Learning Sciences Research Center, University of Cincinnati \\ 2150 Q Edwards Hall, Cincinnati, Ohio 45221-0105, United States \\ Tel: 1-513-566-0555Ｅ-mail: Marcus.Johnson@uc.edu
}

Received: Sep. 19, 2013 Accepted: Ocotber 2, 2013 Published: February 1, 2014

doi:10.5296/jse.v4i1.4306 URL: http://dx.doi.org/10.5296/jse.v4i1.4306

\begin{abstract}
In this paper the results of a simultaneous regression analysis concerning achievement motivation for introductory college biology are presented. A total of 287 undergraduates enrolled in introductory-level college biology courses participated in this study. Participants completed a survey consisting of items from the Motivated Strategies for Learning Questionnaire, demographic information, and academic achievement. Results indicate that $68 \%$ of the variation in biology students' achievement can be explained by a combination of motivational constructs, intrinsic goals, extrinsic goals, task value, control beliefs, self-efficacy, and test anxiety; with self-efficacy being the strongest predictor. Implications and future directions are discussed.
\end{abstract}

Keywords: Self-efficacy, Motivation, Biology, Undergraduate, College students 


\section{Introduction}

Of the core sciences (biology, chemistry, and physics), the biological sciences stake claim to having the largest student enrollment (National Center for Education Statistics, 2006), and claim responsibility for preparing individuals for health and environmental related careers (Eyster, 2007). Nevertheless, the biological sciences face some adversity with combating students' low achievement, particularly in introductory-level biology courses. According to Congos, Langsam, and Schoeps (1997), up to half of students enrolled in introductory biology courses at many colleges and universities earn a letter grade of ' $D$ ' or ' $F$ ', if not withdraw from the courses entirely. Students having to enroll in introductory-level science courses have expressed "the boring memorization of jargon and formulas; the grade curves; the 'weeder' function; and the lack of community in large, introductory science courses" (Brand, 1994, p. 182). Before one can obtain a college degree, particularly a degree in the sciences, one must first achieve in introductory-level biology classes. The difficulty, however, in combating low achievement in such courses involves addressing the many factors that adversely influence students' academic behaviors and performance. One of these major factors under investigation is students' motivation.

It is well documented that academic motivation has been strongly associated with students' academic behaviors in college science courses, including strategy use (Zusho, Pintrich, \& Coppola, 2003), the tasks students choose to pursue (Moore, 2005), and consequently, achievement (Bandalos, Finney, \& Geske, 2003; Duncan \& McKeachie, 2005; Lin, McKeachie, \& Kim, 2001). The research in science education points to the importance of six motivational constructs, including self-efficacy, task-value, control of learning beliefs, test-anxiety, intrinsic motivation, and extrinsic motivation (Zusho, Pintrich, \& Coppola, 2003) that play a role in influencing achievement. Often found to be a strong predictor of college achievement (Lawson, Banks, \& Logvin, 2007; Lynch, 2006), self-efficacy can be defined as one's belief that a desired outcome, on a specific task, can be produced (Bandura \& Locke, 2003; see also, Pajares, 1996; Usher \& Pajares, 2008). In a multi-wave study with college students enrolled in introductory-chemistry courses, self-efficacy is found to be one of the strongest predictors of students' final course performance (Zusho, Pintrich, \& Coppola, 2003). A construct that is strongly related to self-efficacy, is the motivational construct, control of learning beliefs, which can be defined as an individuals' expectations that controlling personal efforts on a learning task will result in positive outcomes (Sungur, 2007). In a study of first year college students, McKenzie, Gow, \& Schweitzer (2004) identify control for learning beliefs, to have an indirect effect on student achievement when mediated by students' learning strategy use.

In addition to the role self-efficacy and control beliefs may have in student achievement, Glynn, Taasoobshirazi, and Brickman (2006) illustrated in a path analysis that students' belief in the relevance of biology to their career (task value) had a significant positive direct effect on achievement. Moore (2007), along with Bruning (2007), contend that the lack of task-value towards introductory-level biology courses may be a detrimental factor to achievement, as both Moore and Bruning observe that students often view tasks in introductory biology courses as "unimportant." Therefore, Bruning challenges science educators to identify what is valued by students in science courses. A construct that 
Bembenutty (2008) argues can decrease both self-efficacy and allow an individual to devalue important learning outcomes, is test-anxiety. Test-anxiety, the degree to which a student has concern or worry over taking exams, has been found to be negatively associated with achievement in biology courses (Sansgiry, Bhosle, \& Dutta, 2005), as well as biopsychology college students (Sgoutas-Emch, Nagel, \& Flynn, 2007).

Despite the strong associations between self-efficacy, task-value, test-anxiety, and students' science achievement, intrinsic and extrinsic motivation tend to illustrate less stable associations. Whereas intrinsic motivation involves participating in a task because it is inherently rewarding (Sheldon \& Kasser, 1995), extrinsic motivation involves participating in a task as a means to an end (i.e. money). In a 2001 study with college biology students, Lin, McKeachie, and Kim found that students who had high intrinsic motivation and moderate extrinsic motivation, yielded better grades than those who had extreme (high and low) extrinsic motivation.

Although research does show that low motivation is linked to low achievement in biology, my intent is to investigate the degree to which the aforementioned motivational constructs contribute to college students' biology achievement, specifically those enrolled in introductory-level college biology courses. An understanding of which motivational factors best predict college biology achievement can help inform college educators about the specific motive(s) that may garner higher achievement in biology. Implications of this study's results may provide valuable insight as to what motivational strategies/interventions college biology instructors and other student services personnel who interact with college biology students may employ to enhance their students' achievement experiences.

\section{Method}

\subsection{Participants}

A total of 287 undergraduate students (205 females and 82 males) ${ }^{1}$ enrolled in five sections of a required introductory level biology course for science majors, at two large, public, urban, college institutions in the Southwestern region of the United States, participated in this study. The bulk of participants were in their sophomore year $(43 \%)$, followed by freshmen $(21 \%)$, juniors (19\%), and seniors (17\%). Approximately 50\% of participants reported having a biology major, followed by $23 \%$ reporting nursing majors, $23 \%$ reporting "other" science related majors, and 4\% undecided. Approximately $48 \%$ of the sample identified as being Caucasian, followed by $24 \%$ identifying as Asian/Pacific-Islander decent, $13 \%$ Hispanic/Latino decent, 6\% Blackk/African-American, 3\% Native American, and 6\% other. Participants from the sample also reported an average cumulative grade-point-average of 3.16 [on a 4.0 scale] $(\mathrm{SD}=.66)$.

\subsection{Measures}

\subsubsection{Motivation}

To access students' motivation, 31 (7-point Likert-scale) items derived from the motivation

\footnotetext{
1 The greater number of female participants in my sample can be attributed to the unequal gender distribution at the institutions, and the biology courses themselves, which enroll more females than males.
} 
scale of the Motivated Strategies for Learning Questionnaire [MSLQ] (Duncan \& McKeachie, 2005; Pintrich, Smith, Garcia, \& McKeachie, 1993) were used; consisting of subscales for intrinsic goal orientation (4 items), extrinsic goal orientation (4 items), task value (6 items), control of learning beliefs ( 4 items), self-efficacy for learning and performance ( 8 items), and test anxiety (5 items). Using a social-cognitive view of motivation and learning strategies, the MSLQ has been an established and invaluable self-report tool (Duncan \& McKeachie, 2005) for many researchers, educators, and students for a wide variety of different purposes and contexts. Duncan and McKeachie (2005) report Cronbach alpha reliability coefficients ranging from .62 to .93 for the motivation subscales, with intrinsic goal orientation, test anxiety, task value, and self-efficacy having acceptable to excellent consistency. Though Duncan and McKeachie (2005) report questionable internal consistency values for control beliefs and extrinsic goal orientation, in the present study, Cronbach alpha reliability coefficients ranging from .77 to .95 were obtained for the same MSLQ subscales (see Table 1 ); indicating that participants in this sample were consistent in their responses to items respective of each of the MSLQ motivation subscales. In addition to having acceptable reliability, Pintrich et al. (1993) reported that with exception to the extrinsic goal orientation subscale, that the MSLQ had reasonable predictive validity, as the remaining motivation subscales were strong predictors of college students' final course grades (in various subject matters).

\subsubsection{Achievement}

College biology students' achievement was determined by participants' self-reported responses to "what is your current grade for this biology class." Students' actual grades for their courses could not be obtained from instructors. Sawyer (1988) suggests that despite obtaining students' actual grades is recommended, students' self-reported grades are sufficiently accurate (Cassady, 2001) and useful in many contexts. To minimize students' "overreporting" of their grades, students responded to a second grading item, "what is your expected grade for this biology class." Both of the grade items (current versus expected) were strongly correlated at $.81(\mathrm{p}<.001)$, suggesting that students' self-reporting of grades was consistent. Students' responses to the item "current grade" were used to denote achievement, since it pertained specifically to how students' were performing at the time of data collection.

Table 1. Reliabilities of MSLQ Subscales

\begin{tabular}{|cc|}
\hline Scale/Subscales & Cronbach's Alpha \\
\hline Motivation (MSLQ) & .928 \\
- Intrinsic Goals & .823 \\
- Extrinsic Goals & .776 \\
- $\quad$ Task Value & .930 \\
$-\quad$ Control Beliefs & .842 \\
$-\quad$ Self-Efficacy & .951 \\
$-\quad$ Test Anxiety & .823 \\
\hline
\end{tabular}




\subsection{Procedures and Design}

Data was collected during the $14^{\text {th }}$ week of a 15 week Fall semester. Four instructors agreed to post a survey link onto their course webpages. In accordance with an approved institutional review board (IRB) protocol, students were asked to partake in a 10-minute online survey that assesses students' attitudes and perceptions toward their biology education. Students had until the weekend, prior to their final exam, to complete the survey. Student scores for each of the MSLQ subscales were computed using the Statistical Package for Social Sciences (SPSS). A simultaneous regression analysis (Tai, Sadler, \& Mintzes, 2006) was employed to determine the predictability of the aforementioned motivational constructs on achievement.

\section{Results}

Simultaneous regression analysis is most appropriate when it is unknown as to what variable should come prior to any other. In a simultaneous regression model, multiple independent variables "are treated simultaneously and on an equal footing" (Williams, 2009, p.1). In this study, the independent variables are intrinsic goals, extrinsic goals, task-value, control beliefs, self-efficacy, and test anxiety; and the dependent variable is student achievement. Results indicate that $68 \%$ of the variation in biology students' achievement can be explained by a combination of motivational constructs, intrinsic goals, extrinsic goals, task value, control beliefs, self-efficacy, and test anxiety, $F(6,270)=37.72, p=.0005$. Of the motivational constructs, self-efficacy $(\beta=.759, \mathrm{p}<.01)$ appears to be the strongest predictor of biology student achievement.

Table 2. Summary of Simultaneous Regression Analyses for Variables Predicting Biology student achievement $(\mathrm{N}=278)$

\begin{tabular}{|lccc|}
\hline & \multicolumn{3}{c|}{ Biology Student Achievement } \\
\cline { 2 - 4 } Variable & $B$ & $S E B$ & $\beta$ \\
\hline Intrinsic Goals & -0.016 & 0.016 & -.078 \\
Extrinsic Goals & -0.004 & 0.012 & -.021 \\
Task Value & 0.000 & 0.010 & .003 \\
Control Beliefs & -0.018 & 0.011 & -.096 \\
Self-Efficacy & 0.065 & 0.007 & $.759^{* *}$ \\
Test Anxiety & -0.009 & -0.008 & -.065 \\
\hline
\end{tabular}

$*_{p}<.05 .{ }^{* *} p<.01$.

\section{Discussion}

Student achievement may be influenced by multiple factors, all of which cannot be explained 
within the constraints of this study. Nevertheless, amongst motivational variables that are discussed more thoroughly in regards to science student achievement, the construct, self-efficacy, was found to be the strongest predictor of biology student achievement. This is not to say that self-efficacy causes biology student achievement, however, suggests that students' beliefs about their ability to obtain a desired outcome on a specific task, in this case biology, contributes strongly to students' achievement in an introductory-level college science course.

Strategies that instructors may consider utilizing, to improve their students' efficacy in introductory level college biology courses may include linking material to recent successes students have experienced, using peer models, and/or reinforcing student effort and persistence, to name a few (Margolis \& McCabe, 2004). Schunk, Pintrich, and Meece (2008) suggest similar approaches, as they advocate educators to employ modeling practices; advocate educators to review materials in small steps; and advocate stressing effort and persistence (for more on sources of self-efficacy, see also Chen \& Usher, 2013; as well as Usher \& Pajares, 2008). The use of models, particularly peer models, can act as vicarious reienforcers of adaptive behaviors. What is meant by this, is that if students see their peers, especially those they identify with, succeed, then self-efficacy may be enhanced. Providing reviews for material and linking material with recent successes may also enhance student self-efficacy, since activating students' memory of materials they have already learned or may be familiar with, can reduce feelings of intimidation when new material is presented; thus, students may become more confident in their ability to master the content and/or obtain a desirable outcome.

Applying the aforementioned strategies to introductory-level college biology courses may involve instructors of such classes adopting practices in which students in a class are invited to participate in demonstrations and/or dedicating some time at the start of class/lab/lecture to review previously covered materials [if such practices are not already being employed]. Future studies pertaining to the influence of motivational factors on college science achievement, should consider investigating the effectiveness and appropriateness of instructional strategies that are aimed at improving college biology students' self-efficacy. Additionally, future studies should strongly consider testing the predictability of motivational constructs on student achievement in alternative contexts, such as upper-division biology courses, science courses for non-science majors, underrepresented populations in science, etc.

\section{Conclusion}

Low achievement in introductory-level biology courses may in part be resultant of low motivation, however, instructional strategies may be employed by science educators to remedy and/or improve student motivation. In this study, self-efficacy was identified as the most influential motivational construct on college biology students' achievement. If college-level science instructors seek strategies to improve student achievement in introductory courses, instructional methodologies such as fostering self-efficacy by utilizing peer models, may be a recommended starting approach. 


\section{Acknowledgement}

I would like to thank Dr. Gita Taasoobshirazi (Kennesaw State University) for her supervision of this study. Also I would like to thank Dr. Andrew Andres (UNLV) for his support, participation, and encouragement of this research.

\section{References}

Bandalos, D.L., Geske, J.A., Finney, S.J. (2003). A model of statistics performance based on achievement goal theory. Journal of Educational Psychology, 95, 604-616. http://dx.doi.org/10.1037/0022-0663.95.3.604

Bandura, A., \& Locke, E.A. (2003). Negative self-efficacy and goal effects revisited. Journal of Applied Psychology, 88, 87-99. http://dx.doi.org/10.1037/0021-9010.88.1.87

Bembenutty, H. (2008). Self-regulation of learning and test anxiety. Psychology Journal, 5, 122-139.

Brand, D.L. (1994). Those students who could have but didn't - - early attrition from college science. Journal of College Science Teaching, 24, 180-183.

Bruning, D. (2007). Valuing the prerequisite course: do you respect what you require? Or do you send mixed messages to your majors. Journal of College Science Teaching, 36, 8-9.

Cassady, J.C., \& ERIC Clearinghouse on Assessment and Evaluation, C. (2001). Self-Reported GPA and SAT Scores. ERIC Digest. (ERIC Document Reproduction Service No. ED458216). Retrieved February 28, 2009, from ERIC database.

Chen, J. A., \& Usher, E. L. (2013). Profiles of the sources of science self-efficacy. Learning and Individual Differences, 24, 11-21. http://dx.doi.org/10.1016/j.lindif.2012.11.002

Congos, D.H., Langsam, D., \& Schoeps, N. (1997). Supplemental Instruction: a successful approach to learning how to learn college introductory biology. The Journal of Teaching and Learning, 2, 2-17.

Duncan, T. \& McKeachie, W.J. (2005). The Making of the Motivated Strategies for Learning $\begin{array}{llll}\text { Questionnaire. } & \text { Educational } & \text { Psychologist, } & 40,\end{array}$ http://dx.doi.org/10.1207/s15326985ep4002_6

Eyster, K.M. (2007). Career counseling: 101+ things you can do with a degree in biology. Advances in Physiology Education, 31, 323-328. http://dx.doi.org/10.1152/advan.00042.2007

Glynn, S.M., Taasoobshirazi, G., \& Brickman, P. (2006). Nonscience majors learning science: a theoretical model of motivation. Journal of Research in Science Teaching, 44, 1088-1107. http://dx.doi.org/10.1002/tea.20181

Lawson, A. E., Banks, D. L., \& Logvin, M. (2007). Self-Efficacy, Reasoning Ability, and Achievement in College Biology. Journal of Research In Science Teaching, 44(5), 706-724. http://dx.doi.org/10.1002/tea.20172

Lin, Y, McKeachie, W.J., \& Kim, Y.C. (2001). College students intrinsic and/or extrinsic 
motivation and learning. Learning and Individual Differences, 13, 251-258. http://dx.doi.org/10.1016/S1041-6080(02)00092-4

Lynch, D.J. (2006). Motivational factors, learning strategies and resource management as predictors of course grades. College Student Journal, 40, 423-428.

Margolis, H., \& McCabe, P.P. (2004). Self-efficacy a key to improving the motivation of struggling learners. Clearing House, 241-249. http://dx.doi.org/10.3200/TCHS.77.6.241-249

McKenzie, K., Gow, K., \& Schweitzer, R. (2004). Exploring first-year academic achievement through structural equation modeling. Higher Education Research \& Development, 23, 95-112. http://dx.doi.org/10.1080/0729436032000168513

Moore, R. (2007). Academic motivation and performance of developmental education biology students. Journal of Developmental Education, 31, 24-34.

Moore, R. (2005). Who does extra-credit work in introductory science courses? Journal of College Science Teaching, 34, 12-15.

National Center for Education Statistics (NCES). (2006). Table 294: Degrees in the physical science and science technologies conferred by degree-granting institutions, by level of degree and sex of student: Selected years, 1959-60 through 2004-05. Washington, DC: U.S. Department of Education.

Pajares, F. (1996). Self-efficacy beliefs in academic settings (English). Review of Educational Research, 66(4), 543-578. http://dx.doi.org/10.3102/00346543066004543

Pintrich, P.R., Smith, D.A., Garcia, T., \& McKeachie, W.J. (1993). Reliability and predictive validity of the Motivated Strategies for Learning Questionnaire (MSLQ). Educational and Psychological Measurement, 53, 801-813. http://dx.doi.org/10.1177/0013164493053003024

Sansgiry, S.S., Bhosle, M, \& Dutta, A.P. (2005). Predictors of test anxiety in doctor of pharmacy students: an empirical study. Pharmacy Education, 5, 121-129. http://dx.doi.org/10.1080/15602210500176941

Sawyer, R., \& Others, A. (1988). Accuracy of Self-Reported high School Courses and Grades of College-Bound Students. (ERIC Document Reporduction Service No. ED300458) Retrieved February 28, 2009, from ERIC database.

Schunk, D.H., Pintrich, P.R., \& Meece, J.L. (2008). Motivation in education: Theory, research, and application ( $3^{\text {rd }}$ edition). Upper Saddle River, NJ: Pearson Education.

Sgoutas-Emch, S.A., Nagel, E., \& Flynn, S. (2007). Correlates of performance in biological psychology: how can we help? Journal of Instructional Psychology, 34, 46-53.

Sheldon, K.M., \& Kasser, T. (1995). Coherence and congruence: two aspects of personality integration. Journal of Personality \& Social Psychology, 68, 531-543. http://dx.doi.org/10.1037/0022-3514.68.3.531 
Sungur, S. (2007). Modeling the relationships among students' motivational beliefs, metacognitive strategy use, and effort regulation. Scandinavian Journal of Educational Research, 51, 315-326. http://dx.doi.org/10.1080/00313830701356166

Tai, R.H., Sadler, P.M., \& Mintzes, J.J. (2006). Factors influencing college science success. Journal of College Science Teaching, 36, 52-56.

Usher, E. L., \& Pajares, F. (2008). Sources of Self-Efficacy in School: Critical Review of the Literature and Future Directions. Review of Educational Research, 78(4), 751-796. http://dx.doi.org/10.3102/0034654308321456

Williams, R. (2009). Analytic Strategies: Simultaneous, hierarchical, and Stepwise Regression. Obtained from http://www.nd.edu/ rwilliam/stats1/ on February 28, 2009.

Zusho, A., Pintrich, P.R., \& Coppola, B. (2003). Skill and will: the role of motivation and cognition in the learning of college chemistry. International Journal of Science Education, 25, 1081-1094. http://dx.doi.org/10.1080/0950069032000052207

\section{Copyright Disclaimer}

Copyright reserved by the author(s).

This article is an open-access article distributed under the terms and conditions of the Creative Commons Attribution license (http://creativecommons.org/licenses/by/3.0/). 